\title{
Economic Analysis on Attributes of Workers and Method to Take Annual Paid Vacation
}

\author{
Go Igusa \\ Matsuyama University, Matsuyama, Japan \\ Email: gigusa@cc.matsuyama-u.ac.jp
}

Received 3 July 2015; accepted 22 August 2015; published 25 August 2015

Copyright (C) 2015 by author and Scientific Research Publishing Inc.

This work is licensed under the Creative Commons Attribution International License (CC BY). http://creativecommons.org/licenses/by/4.0/

c) (†) Open Access

\begin{abstract}
This paper focuses on what type of laborers chooses which of the six types of uses of paid vacations. In this paper, we conduct a multinomial logistic regression analysis with the "six types of uses of paid vacations" which are "share method", "progressive method", "regressive method", "self-pay method (advance)", "self-pay method (arrears)", and "self-pay method (work at home)" as object variables. As a result, many of the independent variables did not influence which type was chosen, but interesting variables "information is not shared" and "those around me take paid vacation" were influential, revealing that different types of choices are made depending on how participants work.
\end{abstract}

\section{Keywords}

Issue of Annual Paid, Six Types of Uses of Paid Vacations, Share Method, Progressive Method, Regressive Method, Self-Pay Method (Advance, Arrears, and Work at Home)

\section{Introduction}

The Ministry of Health, Labor and Welfare presented a report that described a request to companies to implement a structure to allow workers to take five or more days per year of annual paid vacation (or "paid vacation”) to the Subcommittee of the Labor Policy Council on February 6, 2015. It aims at improving the use rate of paid vacation which still remains at a low level, specifying the target as "workers who have 10 or more days of paid vacation per year”. A proposal to revise the Labor Standards Act will be submitted to the current Diet session.

The use rate of paid vacation for workers in 2013 increased by 1.7 points in comparison with the previous year, while it still remains at a low level: $48.8 \%$. Only "implementing the structure to allow workers to take five or more days per year of paid vacation" is far from the goal to raise the use rate to $70 \%$ by 2020 as proposed by the government. The number of new paid vacation granted to each employee during the year of 2013 was 18.5 days on average; however, the actual days taken were nine days. Paid vacation developed as a legal system in 
major advanced countries, while the paid vacation system in Japan remains to be significantly weaker when it is compared with major countries with an advanced paid vacation system. However, some changes are observed in the awareness to "work" by Japanese people in recent years, and awareness of "not using paid vacation" is shifting to "unable to use paid vacation," suggesting the need of research and study to contribute to promote the use of paid vacation. In order to present measures to promote the use of paid vacation, this paper clarifies the "operation of paid vacation" as the largest factor that is interfering the use of paid vacation with the approach of economics that produced excellent previous studies on paid vacation.

\section{Previous Studies}

In light of the interest in this paper to multilaterally understand and clarify the "operation of paid vacation," previous studies that are deemed important are chronologically summarized and reviewed, followed by presentation of tasks.

Igusa (2011) [1] combined research results and accomplishments in Matsuzaki (1982) [2] indicating the method to calculate the markup ratio of no work in consideration of paid vacation for the line operation section in the manufacturing industry with advanced division of labor and cooperation, as well as in Wakisaka (2002) [3] clarifying two methods used for operation of childcare leave at a workplace, for the purpose of analyzing them with a qualitative and descriptive study method, clarifying the difference in characteristics of the rotation pattern for the use of paid vacation, and discovering types of behaviors to secure replacements.

Specifically, "six types in the use of paid vacation" are defined as follows.

1) Share method: Coworkers share a small portion of duties of the person who is taking paid vacation. The share method was observed in a workplace where there are relatively many employees who perform the same duties. People taking paid vacation used this method the most, and the use rate of paid vacation was also high.

2) Progressive method: Duties are delegated to a person one level lower than the person taking paid vacation. This was mainly used in the case of workers in managerial roles. There are fewer people who perform the same duties when the job level is higher even if there are many workers in the workplace; therefore the " 1 . Share method" is difficult to function and workers with higher job levels take paid vacation with the "progressive method."

3) Regressive method: A supervisor, etc. of the person taking paid vacation who belongs to the same group, team, section, etc. performs the duties of the person taking paid vacation. This regressive method was observed at a workplace with relatively less manpower as well as less employees who perform the same duties. The supervisor needs to have some understanding to the use of paid vacation in the case of this method.

4) Self-pay method (advance, arrears, and work at home): Instead of delegating another person to perform the duties on the day of paid vacation, the person taking the paid vacation performs them on his own. The use rate of paid vacation for employees who take paid vacation with this method is relatively low. This is often observed in the case where the workload is heavy on a routine basis and the management or supervisors do not have understanding to the use of paid vacation.

In Igusa (2014) [4], the actual situation of the relationship between six types (of acquisition methods) and the use rate of paid vacation was confirmed in accordance with a questionnaire survey in reference to the study results of Igusa (2011) [1], and verified by conducting a censored model regression analysis with the number of paid vacation taken as the dependent variable. A clear disparity in the number of paid vacation taken depending on the use method was supposed to be clarified; however there is a significant difference in the sample size for each use method, and besides, the sample size for two types (progressive method and work at home) was 10 or less, causing difficulties in accurately understanding the relationship between six types and the use rate of paid vacation. In Igusa (2014) [5], therefore, samples for each use method were extracted from each class of a different size to make them about the same number in order to equalize the power of test for each use method, and the relationship was once again verified by conducting a censored model regression analysis with the number of paid vacation taken as the dependent variable. As a result, the number of paid vacation taken was significantly small for people who take paid vacation with the "arrears" and "work at home" in the self-pay method. In other words, the use status of paid vacation may possibly be improved by avoiding the "self-pay method" at least, where burdens at the time of taking paid vacation are heavy. Therefore, the study is further deepened in this paper to quantitatively clarify what kind of people select each type with empirical analysis and obtain a clue to promote the use of paid vacation. 


\section{Overview of Questionnaire Survey and Major Aggregate Results}

The target included regular employees ages 20 to 59 in Japan among monitors retained by the private professional research company (Borders) by using the Internet (employees ages 20 to 59 were sampled in accordance with the scope of ages in the recent "survey on the use of annual paid vacation"). This research firm is used even by major think tanks, universities, and the like, so their survey methods as well as samples have a certain degree of reliability. The same number was allocated with stratified sampling. The sample size $\mathrm{n}$ for each method will be considerably biased in the case of proportionate sampling; therefore the same number was allocated. Attention was paid not to cause bias in factors that could influence target variables (age, gender, etc.), in order to avoid bias due to grouping such as allocation of the same number ${ }^{1}$. The questionnaire items are about personal attributes such as academic background and marriage status, as well as working styles, number of annual paid vacation days obtained and given, and central concerns such as how yearly paid vacation is obtained. The survey period was seven days from November 27 to December 4, 2013. The number of responses was $687^{2}$, and as a result of excluding invalid responses and processing abnormal values in valid responses, the sample size for analysis turned to be $522^{3,4}$.

\section{Variables, Analysis Method, and Results}

What kind of people selects each type? Verification is in accordance with polynomial logistic regression analysis with "six types in the use of paid vacation" as objective variables, including the "share method", "progressive method”, "regressive method”, "self-pay method (advance)”, "self-pay method (arrears)”, and "self-pay method (work at home)" as detailed in the following.

To consider the relationship between basic attributes as well as ways of working and each type, actual work hours per week, the number of paid vacation granted, and annual income (log) were applied as independent variables in addition to dummy variables on basic attributes and ways of working. Table 1 is indicating descriptive statistics of variables used for analysis, and Table 2 is indicating the results.

Most of the descriptive statistics diverge somewhat from the labor force survey by the Ministry of Internal Affairs and Communications due to sample sizes and the like, but the deviation is slight, and it should not be at a level where it would have any effect on generalizability of the results.

As a result, many independent variables were not influencing selection of each type, while "information is not shared" and "those around me take paid vacation" were interestingly found to be significant variables, suggesting a clear disparity in selection of types depending on ways of working.

\section{Discussion and Conclusions}

People with "information is not shared" at the workplace tend to choose the "self-pay method (work at home)" and people with "those around me take paid vacation" tend to choose the "regressive method", while it is difficult to interpret results from polynomial logistic regression analysis. Table 2 is indicating results of estimating how easy it is to choose "each of the other types" in comparison with the "share method" as the standard category in basic interpretation of polynomial logistic regression analysis. For example, which would people with "information is not shared" choose between the "progressive method" and "self-pay method (work at home)"? This model does not seem like directly comparing both, which can be easily compared with the model established in the beginning. In other words, effects of "information is not shared" in the case of comparing the "progressive method" with the "self-pay method (work at home)" can be obtained by subtracting coefficient values for both variables in Table 2, i.e., $1.434-0.689=0.745$, and people with "information is not shared" tend to choose the "self-pay method (work at home)." Since standard errors cannot be derived from such a simple calculation, significance is unknown. Based on the empirical rule, however, values are not much different from standard errors for "information is not shared” in Table 2, i.e., there is not much difference in the significance.

\footnotetext{
${ }^{1}$ Refer to Igusa (2014) [5] for details. Samples as the basis of analysis in this paper were obtained from the questionnaire survey in Igusa (2014) [5].

${ }^{2}$ Efforts were made not to cause differences in the number of responses for each use method. However, some differences were caused because the distribution of attributes by gender, age, and class in the Census was taken into consideration and the numbers of monitors for the progressive method and self-pay method (work at home) were originally small, while they were not too significant to influence the analysis. ${ }^{3}$ Abnormal values, etc. in the number of paid vacation granted were excluded. Refer to Igusa (2014) [5] for details.

${ }^{4}$ Refer to the statistics in Table 1 and Igusa (2014) [4] in regards to the survey items in the questionnaire. The survey items are almost the same as Igusa (2014) [4].
} 
Table 1. Descriptive statistics.

\begin{tabular}{|c|c|c|c|c|}
\hline Variable name & Average & $\begin{array}{l}\text { Standard } \\
\text { deviation }\end{array}$ & $\begin{array}{l}\text { Maximum } \\
\text { value }\end{array}$ & $\begin{array}{l}\text { Minimum } \\
\text { value }\end{array}$ \\
\hline Age & 40.351 & 10.668 & 59 & 20 \\
\hline Married $^{*}$ & 0.504 & 0.500 & 1 & 0 \\
\hline Male $^{*}$ & 0.513 & 0.500 & 1 & 0 \\
\hline Have children* & 0.402 & 0.490 & 1 & 0 \\
\hline Junior high school graduate/High School graduate ${ }^{*}$ & 0.243 & 0.429 & 1 & 0 \\
\hline Vocational school graduate/graduate of other various schools ${ }^{*}$ & 0.105 & 0.307 & 1 & 0 \\
\hline Junior college/technical college graduate ${ }^{*}$ & 0.096 & 0.294 & 1 & 0 \\
\hline 4-year university graduate ${ }^{*}$ & 0.490 & 0.500 & 1 & 0 \\
\hline Graduate school graduate (completed MFA) or above $^{*}$ & 0.065 & 0.247 & 1 & 0 \\
\hline Manufacturing industry ${ }^{*}$ & 0.234 & 0.423 & 1 & 0 \\
\hline Construction industry ${ }^{*}$ & 0.054 & 0.225 & 1 & 0 \\
\hline Shipping, transportation, telecommunications industry ${ }^{*}$ & 0.063 & 0.243 & 1 & 0 \\
\hline Wholesale, retail, restaurant industry ${ }^{*}$ & 0.111 & 0.314 & 1 & 0 \\
\hline Finance, insurance, real estate industry ${ }^{*}$ & 0.092 & 0.289 & 1 & 0 \\
\hline Service, broadcasting, software, information service industry ${ }^{*}$ & 0.232 & 0.422 & 1 & 0 \\
\hline Public health industry ${ }^{*}$ & 0.061 & 0.240 & 1 & 0 \\
\hline Cooperative association, education-related, civil servant ${ }^{*}$ & 0.119 & 0.324 & 1 & 0 \\
\hline $\begin{array}{l}\text { Agriculture, forestry, fishing, mining, electricity, gas and heat supply, } \\
\text { water, iron and steel, publishing and printing }\end{array}$ & 0.034 & 0.182 & 1 & 0 \\
\hline Number of people in your department & 53.082 & 90.691 & 500 & 1 \\
\hline $\begin{array}{l}\text { Production worker (direct and indirect factory departments } \\
\text { such as processing, assembly, inspection and machine operation) }\end{array}$ & 0.088 & 0.283 & 1 & 0 \\
\hline Clerical position ${ }^{*}$ & 0.517 & 0.500 & 1 & 0 \\
\hline $\begin{array}{l}\text { Professional/technical position (research and development, } \\
\text { design, information processing, teacher, designer, etc.) }\end{array}$ & 0.193 & 0.395 & 1 & 0 \\
\hline Sales and marketing ${ }^{*}$ & 0.102 & 0.302 & 1 & 0 \\
\hline Other $^{*}$ & 0.100 & 0.299 & 1 & 0 \\
\hline Labor union present $^{*}$ & 0.483 & 0.500 & 1 & 0 \\
\hline Annual income & 436.609 & 222.289 & 1500 & 100 \\
\hline Working hours per week & 44.213 & 8.485 & 85 & 20 \\
\hline Days of paid vacation granted & 15.745 & 5.252 & 26 & 5 \\
\hline Share method* & 0.211 & 0.408 & 1 & 0 \\
\hline Progressive method ${ }^{*}$ & 0.117 & 0.321 & 1 & 0 \\
\hline Regressive method ${ }^{*}$ & 0.184 & 0.387 & 1 & 0 \\
\hline Self-pay method (advance) ${ }^{*}$ & 0.192 & 0.394 & 1 & 0 \\
\hline Self-pay method (arrears) ${ }^{*}$ & 0.203 & 0.402 & 1 & 0 \\
\hline Self-pay method (work at home) ${ }^{*}$ & 0.094 & 0.292 & 1 & 0 \\
\hline Information is shared ${ }^{*}$ & 0.605 & 0.489 & 1 & 0 \\
\hline Can't say either way if information is shared ${ }^{*}$ & 0.257 & 0.437 & 1 & 0 \\
\hline Information is not shared ${ }^{*}$ & 0.138 & 0.345 & 1 & 0 \\
\hline There is a feeling of mutual understanding ${ }^{*}$ & 0.525 & 0.499 & 1 & 0 \\
\hline Can't say either way if there is a feeling of mutual understanding* & 0.228 & 0.420 & 1 & 0 \\
\hline There is no feeling of mutual understanding ${ }^{*}$ & 0.247 & 0.431 & 1 & 0 \\
\hline The workload is managed appropriately commensurate with the personnel ${ }^{*}$ & 0.383 & 0.486 & 1 & 0 \\
\hline $\begin{array}{l}\text { Can't say either way if the workload is managed } \\
\text { appropriately commensurate with the personnel }{ }^{*}\end{array}$ & 0.328 & 0.469 & 1 & 0 \\
\hline The workload is not managed appropriately commensurate with the personnel ${ }^{*}$ & 0.289 & 0.453 & 1 & 0 \\
\hline Those around me take paid vacation ${ }^{*}$ & 0.642 & 0.479 & 1 & 0 \\
\hline Can't say either way if those around me take paid vacation ${ }^{*}$ & 0.163 & 0.369 & 1 & 0 \\
\hline Those around me do not take paid vacation ${ }^{*}$ & 0.195 & 0.397 & 1 & 0 \\
\hline
\end{tabular}

Note (1) sample size = 522; Note (2) ${ }^{*}$ Dummy variable. 
Table 2. Polynomial logistic regression analysis on "six types in the use of paid vacation".

\begin{tabular}{|c|c|c|c|c|c|c|c|c|c|c|}
\hline \multicolumn{11}{|c|}{$\begin{array}{l}\text { Objective variables = Share method, Progressive method, Regressive method, } \\
\text { Self-pay method (advance), Self-pay method (arrears), Self-pay method (work at home) }\end{array}$} \\
\hline \multicolumn{11}{|c|}{ Sample size $=522$} \\
\hline \multicolumn{11}{|c|}{ Nagelkerke $=-1637.213$} \\
\hline & \multicolumn{2}{|c|}{$\begin{array}{l}\text { Progressive } \\
\text { method }\end{array}$} & \multicolumn{2}{|c|}{ Regressive method } & \multicolumn{2}{|c|}{$\begin{array}{l}\text { Self-pay method } \\
\quad \text { (advance) }\end{array}$} & \multicolumn{2}{|c|}{$\begin{array}{l}\text { Self-pay } \\
\text { method } \\
\text { (arrears) }\end{array}$} & \multicolumn{2}{|c|}{$\begin{array}{c}\text { Self-pay } \\
\text { method } \\
\text { (work at home) }\end{array}$} \\
\hline & $\begin{array}{l}\text { Coefficient } \\
\text { value }\end{array}$ & $\begin{array}{c}\mathrm{P} \\
\text { value }\end{array}$ & $\begin{array}{l}\text { Coefficient } \\
\text { value }\end{array}$ & $\begin{array}{c}\mathrm{P} \\
\text { value }\end{array}$ & $\begin{array}{l}\text { Coefficient } \\
\text { value }\end{array}$ & $\begin{array}{c}\mathrm{P} \\
\text { value }\end{array}$ & $\begin{array}{l}\text { Coefficient } \\
\text { value }\end{array}$ & $\begin{array}{c}\mathrm{P} \\
\text { value }\end{array}$ & $\begin{array}{l}\text { Coefficient } \\
\text { value }\end{array}$ & $\begin{array}{c}\mathrm{P} \\
\text { value }\end{array}$ \\
\hline Age & 0.000 & 0.989 & -0.015 & 0.371 & -0.016 & 0.351 & -0.004 & 0.818 & 0.000 & 0.993 \\
\hline Married & -0.767 & 0.125 & -0.461 & 0.259 & -0.205 & 0.604 & -0.484 & 0.244 & 0.466 & 0.333 \\
\hline Male & 0.829 & 0.079 & 0.024 & 0.953 & 0.331 & 0.408 & 0.435 & 0.266 & -0.323 & 0.517 \\
\hline Have children & 1.207 & $0.020^{*}$ & 0.514 & 0.232 & 0.538 & 0.199 & 0.770 & 0.078 & -0.071 & 0.889 \\
\hline \multicolumn{11}{|l|}{$\begin{array}{l}\text { (Junior high school } \\
\text { graduate/High School graduate) }\end{array}$} \\
\hline $\begin{array}{l}\text { Vocational school graduate/graduate } \\
\text { of other various schools }\end{array}$ & 0.495 & 0.464 & -0.148 & 0.784 & -0.312 & 0.600 & 0.030 & 0.958 & 0.069 & 0.916 \\
\hline Junior college/technical college graduate & 1.564 & $0.035^{*}$ & 0.708 & 0.267 & 1.026 & 0.107 & 1.069 & 0.088 & 0.792 & 0.300 \\
\hline 4-year university graduate & 1.244 & $0.018^{*}$ & -0.122 & 0.761 & 0.187 & 0.655 & -0.160 & 0.701 & 0.152 & 0.768 \\
\hline $\begin{array}{l}\text { Graduate school graduate } \\
\text { (completed MFA) or above }\end{array}$ & 0.365 & 0.713 & -1.574 & 0.173 & 0.943 & 0.160 & 0.320 & 0.634 & 0.682 & 0.419 \\
\hline \multicolumn{11}{|l|}{ (Manufacturing industry) } \\
\hline Construction industry & 1.393 & 0.157 & 1.128 & 0.239 & 1.407 & 0.132 & 2.053 & $0.022^{*}$ & 1.508 & 0.129 \\
\hline $\begin{array}{l}\text { Shipping, transportation, } \\
\text { telecommunications industry }\end{array}$ & -0.689 & 0.386 & 0.151 & 0.820 & -0.160 & 0.835 & -2.008 & 0.083 & 0.078 & 0.920 \\
\hline Wholesale, retail, restaurant industry & 0.197 & 0.798 & 1.154 & 0.079 & 1.724 & $0.007^{* *}$ & 1.278 & 0.059 & 1.006 & 0.188 \\
\hline Finance, insurance, real estate industry & -0.956 & 0.198 & 0.218 & 0.710 & 0.099 & 0.870 & -0.066 & 0.917 & -0.974 & 0.291 \\
\hline $\begin{array}{l}\text { Service, broadcasting, software, } \\
\text { information service industry }\end{array}$ & 0.307 & 0.552 & 0.064 & 0.898 & 0.357 & 0.445 & 0.562 & 0.249 & -0.348 & 0.549 \\
\hline Public health industry & -0.611 & 0.469 & 0.011 & 0.987 & -0.123 & 0.866 & -0.735 & 0.361 & -0.781 & 0.364 \\
\hline $\begin{array}{l}\text { Cooperative association, } \\
\text { education-related, civil servant }\end{array}$ & -1.512 & 0.051 & -0.542 & 0.386 & -0.526 & 0.384 & 0.781 & 0.131 & -1.337 & 0.102 \\
\hline $\begin{array}{l}\text { Agriculture, forestry, fishing, mining, } \\
\text { electricity, gas and heat supply, water, iron } \\
\text { and steel, publishing and printing }\end{array}$ & -0.052 & 0.960 & 0.606 & 0.476 & 0.301 & 0.723 & 0.432 & 0.640 & 0.447 & 0.668 \\
\hline Number of people in your department & 0.001 & 0.584 & 0.000 & 0.947 & -0.001 & 0.535 & 0.000 & 0.820 & 0.001 & 0.421 \\
\hline $\begin{array}{l}\text { Production worker (direct and indirect } \\
\text { factory departments such as processing, } \\
\text { assembly, inspection and machine operation) }\end{array}$ & -1.195 & 0.126 & 0.142 & 0.816 & -0.571 & 0.354 & -1.486 & $0.040^{*}$ & -0.384 & 0.632 \\
\hline \multicolumn{11}{|l|}{ (Clerical position) } \\
\hline $\begin{array}{l}\text { Professional/technical position (research } \\
\text { and development, design, information } \\
\text { processing, teacher, designer, etc.) }\end{array}$ & -0.668 & 0.193 & -0.614 & 0.237 & -0.706 & 0.120 & -0.766 & 0.079 & 0.058 & 0.922 \\
\hline Sales and marketing & -0.758 & 0.232 & 0.588 & 0.231 & -1.615 & $0.010^{*}$ & -1.417 & $0.024^{*}$ & -0.170 & 0.801 \\
\hline Other & -0.685 & 0.274 & 0.460 & 0.359 & -1.761 & $0.014^{*}$ & -2.116 & $0.002^{* *}$ & 0.853 & 0.153 \\
\hline Labor union present & 0.593 & 0.123 & 0.151 & 0.651 & -0.465 & 0.170 & 0.392 & 0.247 & -0.225 & 0.594 \\
\hline Annual income (log) & -0.997 & $0.047^{*}$ & 0.184 & 0.688 & 0.239 & 0.596 & -0.457 & 0.294 & 0.114 & 0.837 \\
\hline Working hours per week & 0.026 & 0.262 & 0.015 & 0.479 & 0.021 & 0.322 & 0.025 & 0.236 & 0.029 & 0.225 \\
\hline Days of paid vacation granted & -0.019 & 0.592 & 0.031 & 0.328 & 0.031 & 0.308 & 0.073 & $0.023^{*}$ & 0.059 & 0.137 \\
\hline Information is shared & 0.062 & 0.887 & 0.349 & 0.359 & 0.259 & 0.478 & 0.100 & 0.783 & 0.545 & 0.259 \\
\hline
\end{tabular}




\section{Continued}

\begin{tabular}{|c|c|c|c|c|c|c|c|c|c|c|}
\hline $\begin{array}{l}\text { (Can’t say either way if } \\
\text { information is shared) }\end{array}$ & & & & & & & & & & \\
\hline Information is not shared & 0.689 & 0.274 & 1.029 & 0.065 & 0.561 & 0.307 & 0.198 & 0.725 & 1.434 & $0.031^{*}$ \\
\hline $\begin{array}{c}\text { There is a feeling of mutual understanding } \\
\text { (Can't say either way if there is } \\
\text { a feeling of mutual understanding) }\end{array}$ & -0.104 & 0.814 & -0.201 & 0.607 & -0.602 & 0.110 & -0.050 & 0.898 & 0.604 & 0.271 \\
\hline There is no feeling of mutual understanding & -0.511 & 0.348 & -0.209 & 0.650 & -0.500 & 0.270 & 0.287 & 0.529 & 0.710 & 0.248 \\
\hline $\begin{array}{l}\text { The workload is managed appropriately } \\
\text { commensurate with the personnel } \\
\text { (Can’t say either way if the workload is } \\
\text { managed appropriately commensurate with } \\
\text { the personnel) }\end{array}$ & 0.240 & 0.585 & 0.259 & 0.500 & 0.217 & 0.573 & -0.133 & 0.728 & -0.524 & 0.256 \\
\hline $\begin{array}{l}\text { The workload is not managed } \\
\text { appropriately commensurate } \\
\text { with the personnel }\end{array}$ & -0.257 & 0.597 & -0.043 & 0.917 & 0.181 & 0.659 & 0.155 & 0.699 & -0.886 & 0.088 \\
\hline $\begin{array}{l}\text { Those around me take paid vacation } \\
\text { (Can’t say either way if those } \\
\text { around me take paid vacation) }\end{array}$ & -0.271 & 0.580 & 0.918 & $0.050^{*}$ & 0.510 & 0.259 & -0.191 & 0.654 & 0.604 & 0.294 \\
\hline Those around me do not take paid vacation & -0.099 & 0.863 & 0.240 & 0.663 & 0.537 & 0.296 & -0.625 & 0.219 & 0.288 & 0.657 \\
\hline
\end{tabular}

Note (1): The standard category = share method; Note (2): Estimated by the author; Note (3): ${ }^{*}=$ significant $@ 5 \%,{ }^{* *}=$ significant $@ 1 \%$, ${ }^{* * *}=$ significant @ $0.1 \%$.

Therefore, not only in the case of "share method" as the standard category but also upon comparison with other types, people with "information is not shared" at a workplace tend to choose the "self-pay method (work at home)" and people with "those around me take paid vacation" tend to choose the "regressive method".

When these results are combined with achievements of previous studies, work cannot be smoothly transferred in the case of "information is not shared" leading to selection of the "self-pay method (work at home)" which gives burdens at the time of taking paid vacation and consequentially imposing restriction on the days to take paid vacation; therefore, workers may hesitate to take paid vacation. Since information is not shared, work becomes the individual's and cannot be taken care of by other people who don't understand the work. When the person is absent, there is no one who can do the work on his behalf; therefore the person taking paid vacation is forced to work at home. In this regard, it may be necessary to develop a structure to cover the same duty by multiple people by strengthening information sharing within an organization by implementing groupware, etc. Since sudden groupware implementation for information sharing will not be utilized, a company and workplace need to begin with creation of a culture to be able to share information.

Another point is that people with "those around me take annual paid vacation" tended to choose the "regressive method," while in a work climate where it is easy to take paid vacation, asking supervisors to cover duties upon taking paid vacation is also easy, and the burdensome "self-pay method" could possibly be avoided. If everyone can fully take paid vacation, it indicates the possibility that the basic rotation of paid vacation functions well, including "follow-up by other people when someone is absent." Companies are required to develop a "work climate where it is easy to take paid vacation."

Nevertheless, many items are not significant, and the detailed analysis at this time did not bring much suggestion when the relationship between basic attributes as well as ways of working and each type was considered. It is the hope for the future to pursue paid vacation with a wider viewpoint in consideration of the relationship with other paid vacation or of integrity by uniformly considering paid vacation, rather than making it very complicated.

\section{References}

[1] Igusa, G. (2011) Six Patterns of Paid Vacation Use: A Study Concerning the Management of Paid Vacation at a Workplace Level. Annual Review of Japanese Association of Labor Sociology, 22, 75-105.

[2] Matsuzaki, T. (1982) Analysis on Steel Industry in Japan. Nippon Hyoron Sha.

[3] Wakisaka, A. (2002) Conditions and Issues for Utilizing Childcare Leave System at a Workplace. Japan Institute of 
Labour Magazine, 44, 4-14.

[4] Igusa, G. (2014) Verification of Hypothesis of "Six Patterns of Paid Vacation Use": An Exploration of Six Patterns of Paid Vacation Usage and Number of Days Taken. Journal of Human Resource and Sustainability Studies (JHRSS), 2, 136-146. http://dx.doi.org/10.4236/jhrss.2014.23013

[5] Igusa, G. (2014) Economic Analysis of Six Methods of Taking Paid Vacation-Labor and Social Science Results and Application. The Annual Report of Economic Science, 52, 1-7. 